Acta Protozool. (2017) 56: 245-254

www.ejournals.eu/Acta-Protozoologica

doi:10.4467/16890027AP.17.022.7824

PROTOZOOLOGICA

\title{
Mobiline Peritrichs (Ciliophora) Collected from the Gills of African Limpets
}

\author{
Liesl L. VAN AS, Linda BASSON, Jo G. VAN AS \\ Department of Zoology and Entomology, University of the Free State, Bloemfontein, South Africa
}

\begin{abstract}
Members of the Urceolariidae Dujardin, 1941 have been found associated with a wide variety of invertebrate hosts from freshwater and marine habitats. Five species have been described from molluscan hosts from Europe and America. This paper deals with an urceolariid (Leiotrocha Fabre-Domergue, 1888) collected from the gills of Cellana radiata capensis (Gmelin, 1791) and Scutellastra exusta (Reeve, 1854) from the east coast of South Africa, as well as Patella depressa Pennant, 1777 and Cymbula safiana (Lamarck, 1891) from the bulge (west coast) of Africa. A higher prevalence was found on C. radiata capensis ( $89 \%)$ and P. depressa (72\%) compared to the other two hosts. The urceolariid collected from the African limpets was identified as L. patellae (Cuénot, 1891). This is the first record of an urceolariid from any African hosts, including representatives of the Mollusca. Five urceolariid species were identified and described from gastropods, i.e. L. patellae Cuénot, 1891, U. karyolobia Hirshfield, 1949, U. cellanae Suzuki, 1950, U. viridis Richards, 1971 and U. parakorschelti Irwin, Sabetrasekh and Lynn, 2017. Motivation is provided why U. cellanae and U. viridis should be reallocated to the genus Leiotrocha, and $U$. karyolobia not. The taxonomic validity of the recent description of $U$. parakorschelti from limpets is commented on.
\end{abstract}

Key words: Urceolaria, Leiotrocha, Mollusca, Gastropoda

\section{INTRODUCTION}

Urceolaria Stein, 1867 (ectosymbionts of freshwater Turbellaria, marine polychaetes and molluscs), Leiotrocha Fabre-Domergue, 1888 (ecto- and endocommensals on marine Mollusca and other invertebrates) and Polycycla Poljansky, 1951 (endocommensals from Holothuroidea), previously regarded as belonging to separate families, are all now placed in one family, i.e. Urceolariidae Dujardin (Noble 1940; Raabe 1963;

Address for correspondence: Liesl L. Van As, Department of Zoology and Entomology, PO Box 339, University of the Free State, Bloemfontein, 9300, South Africa; Fax: + 2751401 9950; E-mail: vanasl1@ufs.ac.za
Beers 1964; Stein 1974; Corliss 1979; Lom and De Puytorac 1994; Lynn 2008).

Host specificity has been recorded for some species by Hirshfield (1950), so it seems highly unlikely that species found on non- gastropod hosts (for example, chitons, bivalves and clams, see Zick 1928; Fenchel 1965; Xu and Song 1998; Irwin and Lynn 2015; Irwin et al. 2017) will also occur on gastropods. For this reason, only the species known from gastropods, i.e. L. patellae (Cuénot, 1891), U. karyolobia Hirshfield, 1949, U. cellanae Suzuki, 1950, U. viridis Richards, 1971 and U. parakorschelti Irwin, Sabetrasekh and Lynn, 2017 were included and compared to the material collected from Africa. Motivation is also provided why U. cellanae and $U$. viridis should be reallocated to the ge- 
nus Leiotrocha, and U. karyolobia not, whilst the taxonomic validity of $U$. parakorschelti is also addressed. Based on morphological features the material collected from the African limpets was identified as Leiotrocha patellae.

\section{MATERIAL AND METHODS}

Limpets were collected from the rocky shore on the east coast of South Africa (Bazley, October 1996, and Mission Rocks at St Lucia, January 1997) and along the west coast (Gorée Island, Senegal, November 1993) of Africa. Molluscan specimens were taken to field laboratories, where the gills were dissected, placed on a microscope slide, smeared and examined using a compound microscope. Wet smears were left to air dry for later impregnation with $\mathrm{AgNO}_{3}$ to obtain detailed information and measurements of the adhesive disc (Klein 1958). Additionally, wet smears were fixed in Bouin's fluid, transferred to $70 \%$ ethanol and stained with Mayer's Haematoxylin (Humason 1979) for studying the nuclear apparatus. In order to study details of the infundibulum, Bouin's-fixed smears were stained with Protargol, using a combined method as described by Lee et al. (1985) and Lom and Dykova (1992). For scanning electron microscopy (SEM), gills were fixed in $10 \%$ buffered neutral formalin. In the laboratory in Bloemfontein, the gills were cleaned by washing with tap-water, dehydrated in a series of ethanol concentrations, critically-point dried, mounted on stubs, sputter-coated with gold and studied at $5 \mathrm{kV}$ using a JOEL WINSEM JSM 6400 scanning electron microscope.

The descriptions are based on mobiline peritrichs found on Cellana radiata capensis (Gmelin, 1971) and Patella depressa Pennant, 1777 as the infestations found on Scutellastra exusta (Reeve, 1854) and Cymbula safiana (Lamarck, 1819) were not high enough to be used for measurements. For comparative purposes, the information from both hosts was kept separate. For body, adhesive disc and nuclear measurements (in $\mu \mathrm{m}$ ) of the specimens, minimum and maximum values are given, followed in parentheses by the arithmetic mean, standard deviation (only in $n>9$ ) and number of specimens measured (see Table 1). Infestation data is provided in Table 2.

Host species names used in the text and in Table 3 have been updated where necessary to include the latest acceptable names for these taxa, using the World Register for Marine Species (WoRMS).

\section{Description of Leiotrocha patellae from South Afri- can limpets (Figs 1A-D, 2A, C, E)}

Host: Cellana radiata capensis (Gmelin, 1791)

Locality: Bazley $\left(30^{\circ} 22^{\prime} \mathrm{S}, 30^{\circ} 40^{\prime} \mathrm{E}\right)$, east coast of South Africa Other host and locality: Scutellastra exusta (Reeve, 1854); Mission Rock at St Lucia

Table 1. Body and nuclear measurements $(\mu \mathrm{m})$ of Leiotrocha patellae (Cuénot, 1891) collected from Cellana radiata capensis (Gmelin, 1791) (Bazley, South Africa) and Patella depressa Pennant, 1777 (Gorée Island, West Africa)

\begin{tabular}{|c|c|c|}
\hline Measurements & Cellana radiata capensis & Patella depressa \\
\hline Body height & $23-33(28.3 \pm 3.7,9)$ & $14-22(17.8 \pm 2.9,6)$ \\
\hline Body diameter & $33-45(37.2 \pm 4.6,11)$ & $30-55(44.6 \pm 6.5,19)$ \\
\hline \multicolumn{3}{|l|}{ Macronucleus } \\
\hline Length of left lobe & $20-49(33.3 \pm 5.0,79)$ & $27-44(34.9 \pm 5.0,37)$ \\
\hline Diameter of left lobe & $2-10(4.1 \pm 1.4,79)$ & $2-7(4.0 \pm 1.2,37)$ \\
\hline Length of right lobe & $10-48(32.0 \pm 5.7,79)$ & $10-46(34.2 \pm 6.1,37)$ \\
\hline Diameter of right lobe & $2-14(4.1 \pm 1.7,79)$ & $2-7(4.3 \pm 1.3,37)$ \\
\hline Length of central part & $5-15(9.1 \pm 1.7,57)$ & $7-16(11.1 \pm 2.0,33)$ \\
\hline Diameter of central part & $5-14(10.8 \pm 2.1,57)$ & $3-18(12.5 \pm 2.9,33)$ \\
\hline Distance between almost fused part of lobes & $1-13(4.0 \pm 2.6,73)$ & $1-15(3.5 \pm 2.9,35)$ \\
\hline Distance between opposite part of lobes & $15-30(20.9 \pm 3.2,79)$ & $17-32(22.9 \pm 4.2,36)$ \\
\hline Micronucleus length & $2-6(3.1 \pm 1.2,21)$ & $1-12(4.5 \pm 3.0,22)$ \\
\hline Micronucleus diameter & $1-5(2.7 \pm 1.1,21)$ & $2-14(6.9 \pm 3.5,22)$ \\
\hline Diameter of adhesive disc & $16-24(21.0 \pm 4.6,12)$ & $21-30(26.3 \pm 2.7,19)$ \\
\hline Diameter of border membrane & $1-2(1.6 \pm 0.5,10)$ & $2-5(2.8 \pm 0.7,19)$ \\
\hline Diameter of denticle ring & $13-21(16.9 \pm 2.4,12)$ & $15-21(18.7 \pm 1.6,19)$ \\
\hline Number of denticles & $15-17(15,12)$ & $11-18(15,19)$ \\
\hline Denticle span & $1-2(1.9 \pm 0.2,12)$ & $1-2(1.8 \pm 0.3,19)$ \\
\hline Distal margin & $1-3(2.6 \pm 0.6,11)$ & $2-4(2.8 \pm 0.5,19)$ \\
\hline Denticle length & $5-7(5.6 \pm 0.9,11)$ & $4-7(4.9 \pm 0.8,19)$ \\
\hline
\end{tabular}


Table 2. Prevalence and infestation index of Leiotrocha patellae (Cuénot, 1891) collected from the gills of African limpets

\begin{tabular}{lll}
\hline Host & Prevalence $\%$ & Infestation index* (Locality) \\
\hline Scutellastra exusta & $36(9 / 25)$ & X (Bazley) \\
Cellana radiata capensis & $85(29 / 34)$ & X-XXX (Mission rock at St Lucia) \\
C. r. capensis & $89(57 / 64)$ & X-XXX (Bazley) \\
Cymbula safiana & $70(7 / 10)$ & X (Gorée Island) \\
Patella depressa & $72(43 / 60)$ & X-XXX (Gorée Island) \\
\hline
\end{tabular}

$\mathrm{X}=$ less than 10 specimens per slide; $\mathrm{XX}=$ between 10 and 100 specimens per slide, $\mathrm{XXX}$ more than 100 specimens per slide. $*$ Range of infestation found among different host specimens.

Table 3. Summary of hosts and distribution records (type and other record) of known urceolariid species collected from gastropod hosts, with applicable references

\begin{tabular}{|c|c|c|c|c|}
\hline L. patellae (Cuénot, 1891) & L. cellanae (Suzuki, 1950) & L. viridis (Richards, 1971) & $\begin{array}{l}\text { U. karyolobia Hirshfield, } \\
1949\end{array}$ & $\begin{array}{l}\text { U. parakorchelti } \\
\text { Irwin, Sabetrasekh and Lynn, } \\
2017\end{array}$ \\
\hline $\begin{array}{l}\text { Patella vulgata Linnaeus, } \\
1758 \\
\text { Roscoff le Portel, France } \\
\text { (Cuénot 1891) }\end{array}$ & $\begin{array}{l}\text { Cellana toreuma (Reeve, } \\
\text { 1854), } \\
\text { Nezugaseki, Japan (Suzuki } \\
\text { 1950) }\end{array}$ & \multirow[t]{4}{*}{$\begin{array}{l}\text { Lottia digitalis (Rathke, } \\
\text { 1833) } \\
\text { California (Richards 1971) }\end{array}$} & $\begin{array}{l}\text { Lottia gigantea Gray in } \\
\text { G.B. Sowerby I } \\
\text { South California (Hirshfield } \\
\text { 1949) }\end{array}$ & $\begin{array}{l}\text { Lottia pelta } \\
\text { Tunstall Bay, Canada (Irwin } \\
\text { et al. 2017) }\end{array}$ \\
\hline $\begin{array}{l}\text { P. aspera Röding, 1798, } \\
\text { P. vulgata, Mediterranean } \\
\text { (Brouardel 1951); } \\
\text { P. caerulea Linnaeus, } 1758 \text {, } \\
\text { North Adriatic Sea (Raabe } \\
\text { 1961); }\end{array}$ & \multirow[t]{3}{*}{$\begin{array}{l}\text { C. eucosmia (Pilsbry, 1892) } \\
\text { (Suzuki 1950) }\end{array}$} & & $\begin{array}{l}\text { Lottia pelta (Rathke, 1833) } \\
\text { L. limatula (Carpenter, } \\
\text { 1864), L. digitalis, } \\
\text { L. fenestrata } \text { Reeve, 1855), } \\
\text { Notoacmea scapha (Suter, } \\
\text { 1907), Discurria insessa } \\
\text { (Hinds, 1842) (Hirshfield } \\
\text { 1949) }\end{array}$ & \multirow[t]{3}{*}{$\begin{array}{l}\text { L. persona (Rathke, 1833) } \\
\text { (Irwin et al. 2017) }\end{array}$} \\
\hline $\begin{array}{l}\text { P. vulgata; } P \text {. ulyssiponensis } \\
\text { Gmelin, } 1791, \text { P. caerulea } \\
\text { Linnaeus, } 1758, \text { Germany } \\
\text { (Haider } 1964 \text { ); }\end{array}$ & & & & \\
\hline $\begin{array}{l}\text { Abra nitida (OF Müller, } \\
\text { 1776), Thyasira sarsi (Philip- } \\
\text { pi, 1845) Scandinavia (Fen- } \\
\text { chel 1965) }\end{array}$ & & & & \\
\hline
\end{tabular}

$\mathrm{C}=$ Cellana $; \mathrm{L}=$ Lottia $; \mathrm{P}=$ Patella .

Reference material: S96/10/10-30; S96/10/10-35 in the collection of the Department of Zoology \& Entomology, University of the Free State, Aquatic Ecology division

Position on host: Gills of limpets

Short cylindrical body with elevated convex peristome (Fig. 1A). Adoral spiral turns $405^{\circ}$ before plunging into infundibulum (Figs 1B, 2E). Haplokinety begins before polykinety, latter enters infundibulum first, followed by haplokinety (Fig. 2E).

Pellicle of most individuals smooth (Fig. 1A). Aboral ciliary girdle consists of single row of marginal cilia, separated by prominent but thin membrane from compound ciliary wreath with eight kinetosomes and single basal cilia ring, latter again separated by a prominent membrane from ciliary girdle (Fig. 1A).
Adhesive disc with scopular cilia ring proximal to denticle ring. Scopular cilia $2 \mu \mathrm{m}$ in length, grouped in pairs (Fig. 1D). Denticles smooth, overlapping like roof tiles (Figs 1C, 2A). Anterior apophysis bluntly rounded, fitting closely against preceding denticle. Distal margin parallel to border membrane (Figs 1D, 2A). Proximal margin not parallel to distal margin, sloping in posterior distal direction. Central part tapers to sharp point. Conical part (Fig. 1C) extends past next denticle adorally for about one quarter length of denticle. Distal central part forming indentation at point of articulation with following denticle. Striated membrane consisting of radial pins $0.8 \mu \mathrm{m}$ wide, extending past denticle to almost centre of adhesive disc (Fig. 1C).

Complex macronucleus (Fig. 2C) in shape of rounded A, consisting of granular lateral lobes with thin connections, meeting 

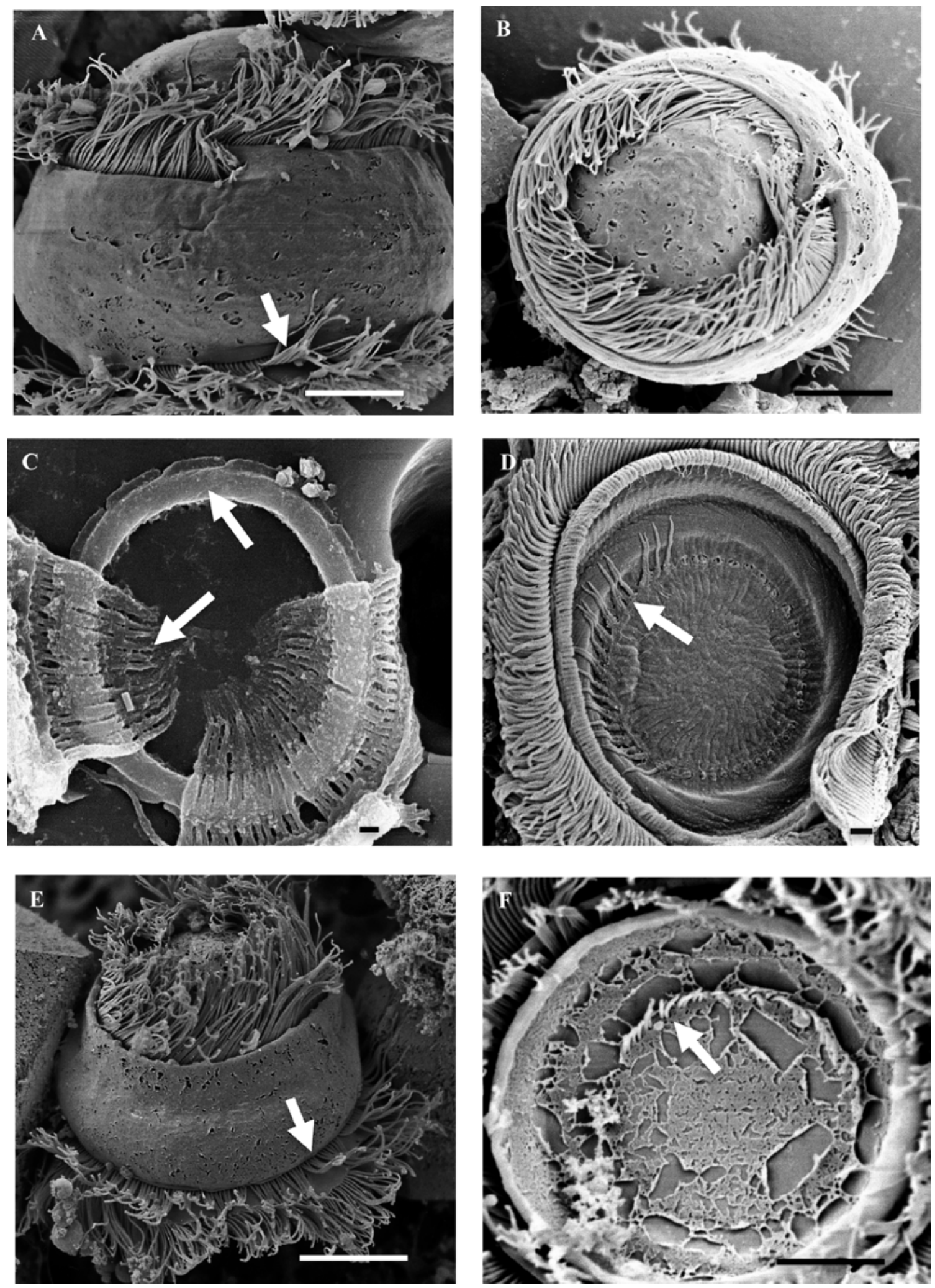

Fig. 1. Scanning electron micrographs of Leiotrocha patellae (Cuénot, 1891) collected from Cellana radiata capensis (Gmelin, 1791) (A-D) from Bazley, South Africa and Patella depressa Pennant, 1777 (E-F) from Gorée Island, West Africa. A and E: Body form with aboral (arrows) and adoral ciliary wreath; B: Adoral view of spiral and ciliary wreath just visible; C: Denticle ring (arrow), soft part dissolved, and striated membrane exposed (arrow); D and F: Scopular cilia (arrow). Scale bar: A, B, E, F = $10 \mu \mathrm{m} ; \mathrm{C}, \mathrm{D}=2 \mu \mathrm{m}$. 

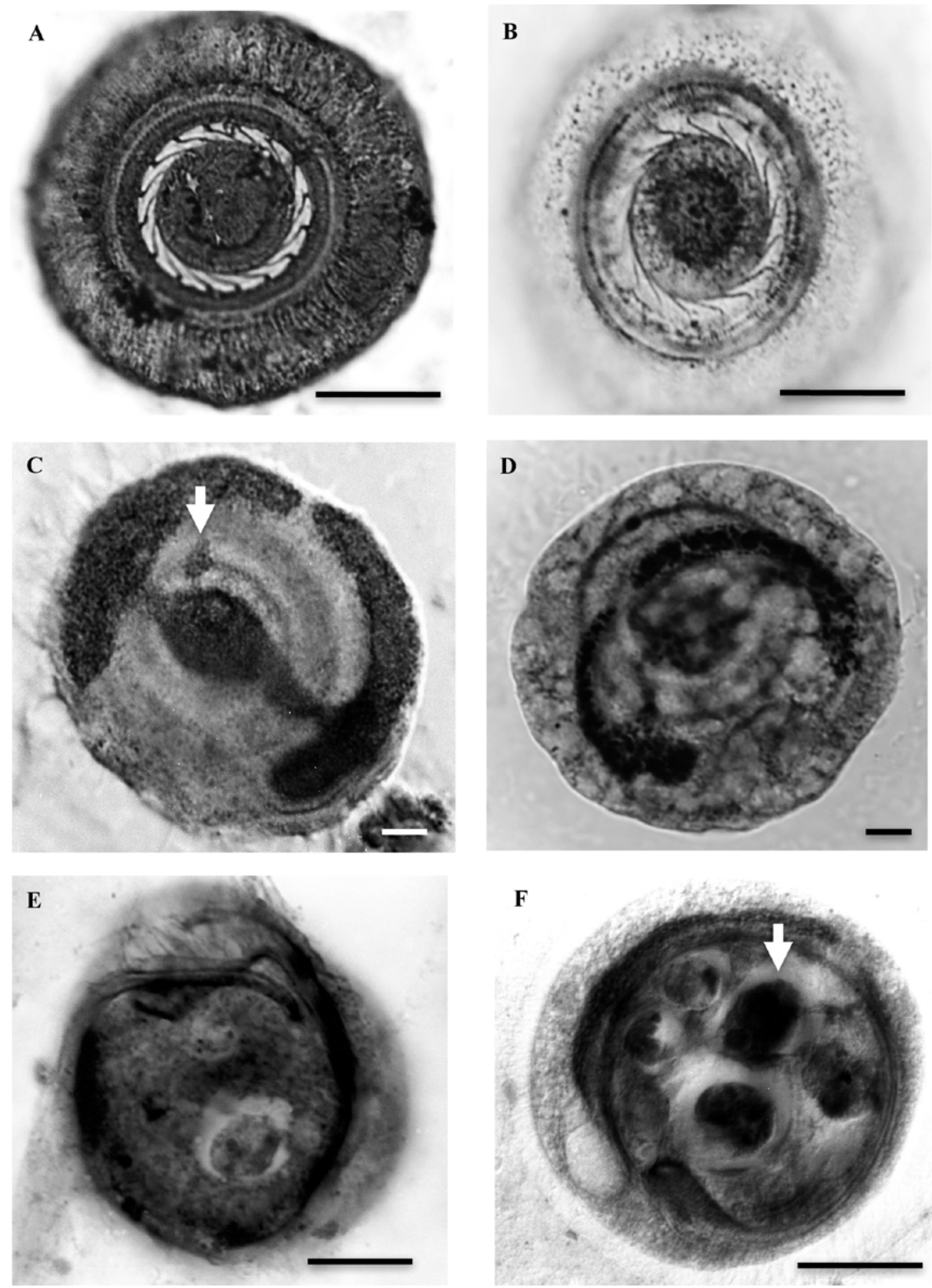

Fig. 2. Light micrographs of Leiotrocha patellae (Cuénot, 1891) collected from Cellana radiata capensis capensis (Gmelin, 1791) (A, C, E) from Bazley, South Africa and Patella depressa Pennant, 1777 (B, D, F) from Gorée Island, West Africa. A and B: Denticle ring; $\mathrm{C}$ and D: Nuclear apparatus - arrow indicate micronucleus; E: Adoral spiral, infundibulum; F: Adoral spiral and body inclusions (arrow). Scale bar: A, B, E, F = $10 \mu \mathrm{m} ; \mathrm{C}, \mathrm{D}=2 \mu \mathrm{m}$. 
in round to oval robust central part. Latter lies closer to aboral side of body, with lateral lobes situated more adorally. In some individuals, lobes appear almost fused at one end, with opposite ends wide apart. Small, round to oval micronucleus lying either in closed or open sector of A-shaped macronucleus (Fig. 2). Central part of macronucleus lying more or less in middle of denticle ring, with lateral lobes closer to periphery of body. Diameter of outer margins of macronucleus larger than adhesive disc diameter. Body measurements and denticle information summarised in Table 1.

\section{Description of Leiotrocha patella from West African limpets (Figs 1E and F, 2B, D, F)}

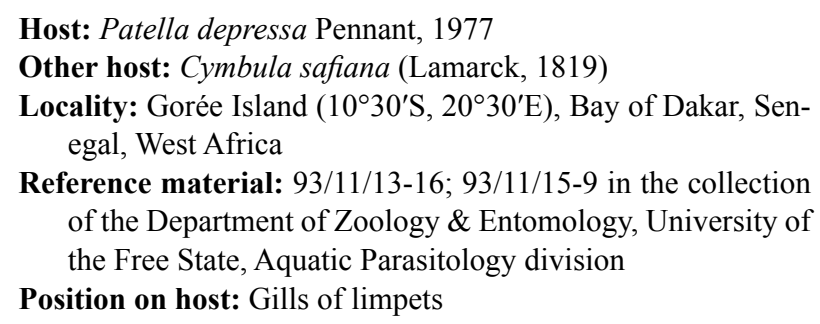

Short cylindrical body (Fig. 1E) with high elevated convex peristome. Some individuals appear more compressed than others. Adoral spiral makes about $405^{\circ}$ turn (Fig. 2F). Outside peristomial lip, haplo- and polykineties show separate rows of kinetosomes before entering buccal cavity. Inside infundibulum polykinety slopes downwards before dividing into three infundibular polykineties. Germinal row supports polykinety just after entering infundibulum. Haplokinety makes another $180^{\circ}$ turn, before entering infundibulum and making a three-quarter turn. At the end of haplokinety an impregnable band is visible. Ends of both kineties come close together before reaching cytostome (Fig. 3).

Aboral ciliary wreath (Fig. 1E) consists of single row of closely spaced marginal cilia, compound ciliary girdle and single basal ring, three groups of cilia separated by two prominent membranes (Fig. 1E). Adhesive disc with ring of scopular cilia (Fig. $1 \mathrm{~F}$ ), cilia $2 \mu \mathrm{m}$ in length, grouped in pairs. Kinetosomes of "lost" scopular cilia form a complete ring. Denticles smooth, overlapping like roof tiles (Fig. 2B). Anterior apophysis fitting closely against preceding denticle. Distal margin parallel to border membrane. Proximal margin not parallel to distal margin, sloping in posterior distal direction. Central part tapers to sharp point, extending past next denticle adorally for about one quarter length of denticle. Distal central part forming indentation at point of articulation with following denticle. Striated membrane consists of radial pins, extending past denticle.

Cytoplasm filled with symbiotic algae (Fig. 2F), hindering observations of internal organelles. Nuclear apparatus (Fig. 2D) consists of A-shaped macronucleus and round to oval micronucleus. Macronucleus has two lateral lobes with thin connections, meeting in round to oval robust central part. One side of lobes almost fused, with opposite ends wide apart. Central part lies closer to aboral side of body, whilst lateral lobes are situated more adorally. Micronucleus small, but prominent in closed part of macronucleus lobes, situated near robust central part. Body measurements and denticle information are summarised in Table 1.

\section{Remarks}

The material from the African continent, which is also the first report and description of a mobiline ciliophoran collected from these limpets, differs significantly from Urceolaria karyolobia and $U$. viridis. Based on the information provided by Irwin and Lynn (2015), and the very limited morphological characteristics given in Irwin et al. (2017) U. parakorshelti also differ from the African material. This leaf two urceolariid species found associated with Patella Linnaeus, 1758 and Cellana H. Adams, 1869 hosts, namely Leiotrocha patellae and U. cellanae (see Brouardel 1951; Raabe 1961; Haider 1964; Fenchel 1965 for the former and Suzuki 1950 for the latter). In comparing the information from the description made by Suzuki (1950), we could not find any significant differences to justify the separation of Suzuki's population of $U$. cellanae from that of the known L. patellae.

The two populations of $L$. patellae collected in the present study from the African limpets are similar in respect to body dimensions (Table 1) and morphological features. Both populations fall within the same range of measurements, although the population from Gorée Island is larger. Both populations show the same variation in the number of denticles (Table 1). The macronucleus is of the same size and shape, displaying similar variations. The only difference appears to be associated with the micronucleus. In the case of the material from Gorée Island, an elongated, rather large oval micronucleus is visible in most of the specimens, with the location in the body appearing to be a constant feature. In the case of the population from the South African east coast (Table 1), however, the micronucleus is slightly smaller when visible, but it is not visible in all specimens of this population.

The most important generic feature for identification, apart from the number of denticles and the shape of the macronucleus, is the presence of the scopular cilia in the centre of the adhesive disc, which is very evident in all specimens of the material examined using SEM (Figs 1D and F).

A high prevalence was found on the gills of Cellana radiata capensis (85\% Mission Rock at St Lucia, 89\% at Bazley) and on Patella depressa (72\% at Gorée). In the case of Cymbula safiana the prevalence seems high $(70 \%)$, but only 10 limpet specimens were examined and less than 10 ciliophorans per slide were found. Scutellastra exusta from the east coast of South Africa had a low prevalence and infestation (Table 2).

Scutellastra exusta and C. r. capensis were only found during the east coast surveys. This is the most southerly point of their distribution range, which extends into the tropical east coast. Both these limpets are found in the Indo-Pacific, as well as South African zoogeographical provinces. They were also the only limpets to be infested with L. patellae as well as Mantoscyphidia branchi Van As, Van As and Basson, 1999. In the case of $S$. exusta the infestation with $L$. patellae was very low and the material was not suitable for a taxonomic description. There is, however, no doubt that $S$. exusta was infested with the same leiotrochid as C. r. capensis. In the latter, only six host specimens harboured a leiotrochid infestation without any mantoscyphidian. In the case of $C . r$. capensis, more than $90 \%$ of all the limpet specimens examined were infested with $M$. branchi, whilst more than $80 \%$ of the populations were also infested with L. patellae. 


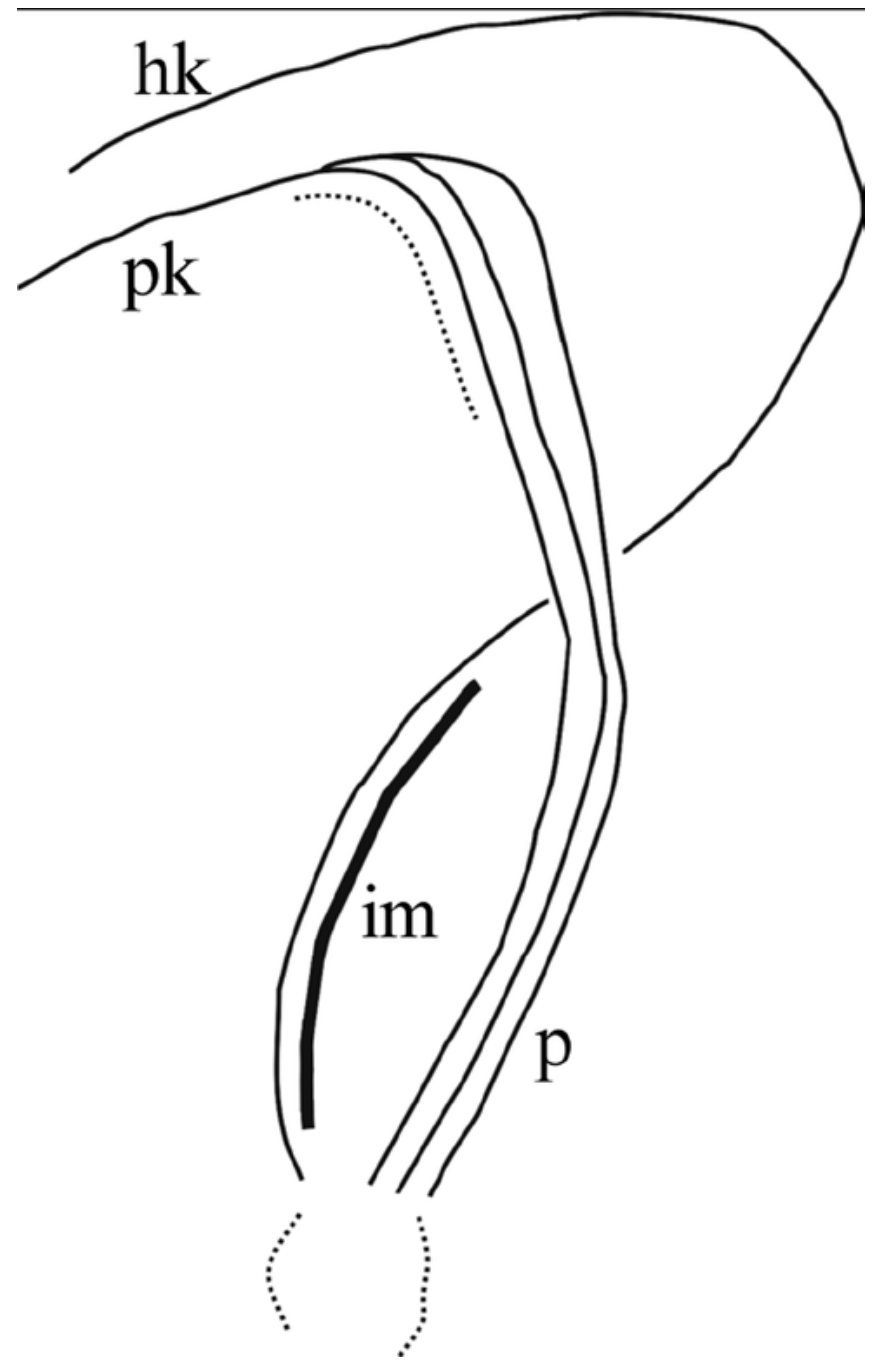

Fig. 3. Line drawing of infundibulum of Leiotrocha patellae (Cuénot, 1891) collected from Patella depressa Pennant, 1777 from Gorée Island, West Africa. hk - haplokinety; im - impregnable band, $\mathrm{p}$ - infundibular polykineties, $\mathrm{pk}$ - polykinety.

\section{DISCUSSION}

Urceolaria species are characterised by a cylindrically shaped body, a $360-400^{\circ}$ adoral spiral, a short conical infundibulum, a wide smooth skeletal ring with up to 20 denticles, no cilia in the centre of the adhesive disc and a compact or horseshoe-shaped macronucleus. Leiotrocha species has a cylindrical- or barrel-shaped body, a $400^{\circ}$ adoral spiral, circular folds on the pellicle, smooth denticles up to 20 in number and scopular cilia present in the centre of the adhesive disc, while the macronucleus is bulbous, with two peripheral projections and a central part.
Raabe (1963) came to the conclusion that Urceolaria and Leiotrocha differ from each other in the character of the nuclear apparatus, as well as other properties and proposed both Urceolaria and Leiotrocha as valid genera. This was furthermore supported by Lom and De Puytorac (1994) stating that the shape of the macronucleus and the absence or presence of the small scopular cilia are of generic importance in differentiating Leiotrocha and Urceolaria from one another.

If the generic diagnosis of Lom and De Puytorac (1994) is followed, some of the known urceolariid species found associated with gastropod hosts should be included within the genus Leiotrocha, and we would like to propose the following:

Hirshfield (1949) described U. karyolobia from North American limpets. An outstanding characteristic of this species is the macronucleus, which is described as "a multilobed mass within which the micronucleus rests". This does not fall within the characteristics of the genus Leiotrocha, so this species must remain in the genus Urceolaria.

Leiotrocha patellae, was initially described as Trichodina patellae Cuénot, 1891 from Patella vulgata Linnaeus, 1758. Hirshfield (1949), Brouardel (1951), Raabe (1961) and Haider (1964) found the same ciliophoran from different Patella species in American, European and Mediterranean waters, which they all identified as $U$. patellae. Fenchel (1965) recorded urceolariids from Scandinavian bivalves, which he identified as L. patellae. In the same article, he synonymised $U$. patellae and U. korschelti Zick, 1928 collected from chitons with the material he collected from bivalves. From the drawings presented in his work, the macronucleus appears different from the other populations of $L$. patellae. Furthermore, it is questionable whether an urceolariid found associated with a bivalve will also inhabit limpets, as urceolariids are known to show host specificity. It is important to note that in the original species description scopular cilia were not noted for $L$. patellae. These cilia are very small $(2 \mu \mathrm{m}$ in length) and sparsely distributed, meaning that most authors in the past have probably overlooked these. In the material collected from the African limpets, we observed these cilia only in SEM micrographs.

Suzuki (1950) described U. cellanae from Cellana toruma (Reeve, 1854) and C. eucosmia (Pilsbry, 1892) in Japan. The adhesive disc of $U$. cellanae is devoid of scopular cilia, which were observed in U. urechi japonica Suzuki, 1950. Based on the nuclear apparatus, the limpet urcleolarid from Japan should, be placed 
in the genus Leiotrocha, it might be that Suzuki just missed the small scopular cilia. In view of the zoogeographical distribution of the hosts, which occur in the Indo-Pacific, Japan and the Red Sea, as well as body morphology, we suggest that the validity of $L$. cellanae (Suzuki, 1950) should be re-examined.

Urceolaria viridis was described from the Californian coast from the gills of Lottia digitalis Rathke, 1833 with an H- to Z-shaped macronucleus, with both ends widely separated (Richards, 1971). Another constant feature of this species is the presence of elongated green algae in the cytoplasm of all the specimens. Caullery and Mesnil (1915) likewise reported on the $10 \mu \mathrm{m}$ size zooxanthellae found in L. patellae. Brouardel (1951) also found zoochlorellae in Leiotrocha specimens he collected from Patella species. We too found round, symbiotic algae in the Leiotrocha populations collected from the limpets from West Africa (Fig. 2F). Due to the shape of the nuclear apparatus and the presence of the delicate scopular cilia, this species from $L$. digitalis should also be reallocated to the genus Leiotrocha, thus be known as L. viridis (Richards, 1971) (see Table 4).

Irwin and Lynn (2015) indicated two separate groups of an urceolariid species from various limpets that they identified as $U$. korschelti, a species not reported from limpets and previously described only from chitons. These authors presented two groups of $U$. korschelti from limpets, an Eastern Pacific population that showed clear genetic divergence from a second group they indicated as a Western Pacific population, forming two well-supported sister clades, with an $8 \%$ difference in the SSU rRNA between these two populations. They proposed that since $U$. korschelti has been identified from the North Sea by Zick (1928), the Western Pacific by Zhan et al. (2012) and the Eastern Pacific by Hirshfield (1949), that $U$. korschelti is a globally distributed species complex and a cryptic species. It needs to be stressed that both Zick (1928) and Hirshfield (1949) described $U$. korschelti from chitons, while Zhan et al. (2012) give no indication of either the hosts or the locality of this species they used in the representation of their Bayesian tree, nor do these authors present a morphological description.

Irwin et al. (2017) collected urceolariids from the type host and type locality of $U$. korschelti, i.e. chitons from Helgoland and distinguished the Eastern Pacific urceolariid population as Urceolaria korschelti. The Western limpet population previously discussed by Irwin and Lynn (2015) is elevated to a new species, i.e. $U$. parakorschelti based on molecular work by Irwin et al. (2017). They did not provide a morphological description at all, but indicate that this will be done at a later stage. DNA work has yet not shown any genetic differentiation, or indeed been addressed by any worker, therefore the genus diagnosis presented by Lom and De Puytorac (1994) should still be considered as the only valid generic differentiation. Irwin et al. (2017) do not provide a sound morphological description of their new species and they also give no indication of whether scopular cilia are present in any of the urceolariids under discussion. Based on the structure of the macronucleus, their species should be considered to belong to the genus Leiotrocha and not Urceolaria, i.e. L. parakorschelti.

Irwin et al. (2017) erroneously indicated that there are only two species of urceolariids known from limpets, i.e. U. karylobia and U. korschelti. This statement is essentially incorrect in two ways: Firstly, there are actually four species (if not taking U. parakorschelti into consideration) and secondly, up to the work of Irwin and Lynn (2015), U. korschelti has only been recorded from chitons, never from limpets, therefore incorrectly identified as from limpets by Irwin and Lynn (2015). The most well-known species from limpets is L. patellae. The other three species also known from limpets are L. cellanae, L. viridis and U. karylobia. The few dimensions Irwin et al. (2017) presented for U. parakorschelti are not acceptable mobiline characteristics at all, i.e. oral diameter, cell diameter and rays per $\mu \mathrm{m}$ of disc circumference. The only valid dimension that they provide is that of the macronucleus.

Since the 1980's different studies have been carried out on the effect of pollutants on aquatic invertebrates (Avtalian 1981; Khan and Kiceniuk 1984; Khan and Thulin 1991; Palm and Dobberstein 1999). These studies showed that an increase in pollutant levels resulted in the destruction of the bacterial symbionts of echinoderms and the proliferation of ciliophoran parasites, especially some Trichodina Ehrenberg, 1830 species as was found by Kahn (1990) in intertidal fish. This in turn has a negative influence on the host fitness. In 2008, Trichodina species were reported for the first time from Patella rustica Linnaeus, 1758 and P. caerulea Linnaeus, 1758 from Turkey along the coast of Antalya Bay (Akşit et al. 2008). The significance of this is the fact that during an earlier study, no symbionts were found and in a short period due to organic pollution from leaks in city sewage, the ciliophorans settled, thus confirming the hypothesis that mobiline peritrichs on molluscan hosts can be an indication of low levels of 
Table 4. Summary of morphological information of known urceolariid species collected from gastropod hosts

\begin{tabular}{|c|c|c|c|c|c|}
\hline & $\begin{array}{l}\text { L. patellae (Cuénot, } \\
\text { 1891) }\end{array}$ & $\begin{array}{l}\text { L. cellanae (Suzuki, } \\
\text { 1950) }\end{array}$ & $\begin{array}{l}\text { L. viridis (Richards, } \\
\text { 1971) }\end{array}$ & $\begin{array}{l}\text { U. karyolobia Hirsh- } \\
\text { field, } 1949\end{array}$ & $\begin{array}{l}\text { U. parakorchelti } \\
\text { Irwin, Sabetrasekh and } \\
\text { Lynn, } 2017\end{array}$ \\
\hline Number of denticles & $12-25$ (ave 18 ) & $13-16$ (ave 14) & $16-22$ (ave 19) & $16-22$ & 17 \\
\hline Scopular cilia & Not mentioned & $\begin{array}{l}\text { Disc floor devoid of } \\
\text { circle of cilia }\end{array}$ & Not mentioned & Not mentioned & Not mentioned \\
\hline Macronucleus & $\begin{array}{l}\text { Lentil-like, compact } \\
\text { central part and } \\
\text { two bow-like bent } \\
\text { elements. }\end{array}$ & $\begin{array}{l}\text { Nearly A but rather } \\
\text { H-shaped }\end{array}$ & H- to Z-shaped & Multi-lobed mass & H-shaped \\
\hline Micronucleus & $\begin{array}{l}\text { Large, situated little } \\
\text { over central part of } \\
\text { macronucleus }\end{array}$ & $\begin{array}{l}\text { Elliptical } 3-5 \mu \mathrm{m} \text { in } \\
\text { length }\end{array}$ & $\begin{array}{l}\text { Round to oval 4-5 } \\
\mu \mathrm{m}\end{array}$ & $\begin{array}{l}\text { Small, lies in cavity } \\
\text { of macronucleus }\end{array}$ & $\begin{array}{l}\text { No information } \\
\text { provided }\end{array}$ \\
\hline Body dimensions $(\mu \mathrm{m})$ & $\begin{array}{l}\mathrm{BH}=40-50 \\
\mathrm{BD}=50-60 \\
\mathrm{BH}=15-50 \\
\mathrm{BD}=27-60 \\
\mathrm{BH}=50 \\
\mathrm{BD}=40-70\end{array}$ & $\begin{array}{l}\mathrm{BH}=16-38 \\
\mathrm{BD}=42-66\end{array}$ & $\begin{array}{l}\mathrm{BD}=25-56(\text { mean } \\
=40)\end{array}$ & $\begin{array}{l}\mathrm{BH}=20-35 \\
\mathrm{BD}=45-60\end{array}$ & $\begin{array}{l}\mathrm{CD}=42-75 \\
\mathrm{OD}=36-55 \\
\mathrm{DR}=24-48\end{array}$ \\
\hline
\end{tabular}

ave $=$ average $; \mathrm{BD}=$ Body diameter; $\mathrm{BH}=$ Body height $\mathrm{CD}=$ Cell diameter; $\mathrm{DR}=$ denticle ring diameter; $\mathrm{OD}=$ Oral diameter.

pollution. However, this record of a trichodinid on $\mathrm{Pa}$ tella species needs verification as the genus Trichodina is not normally found associated with limpets. Akşit et al. (2008) only provided SEM micrographs, making it impossible to confirm the generic and or family status of this occurrence.

The South African coastline with its unique intertidal fauna, finds itself at the turning point of the largest volume of oil tanker traffic in the world. Until recently we have had no major oil spill, but due to the large volume of tanker traffic the risk of chronic low-level pollution is ever increasing, which was the case in 2009 when the Seli 1 stranded at Blouberg Strand, south coast. This was a coal ship that ran on the rocks and only the ship's bunker oil leaked. However, the symbiont populations of molluscs were not monitored in this area before or after the event. From the experience gained in this field it can be predicted that any chronic low-level oil pollution could have a devastating effect on the ciliophoran symbionts of our intertidal organisms.

Of the nearly 30 species of the molluscan genus Cellana, only one occurs on the east coast of South Africa, whilst nine of the 16 species of the genus Scutellastra H. Adams and A. Adams, 1854, and four of the nine Cymbula H. Adams and A. Adams, 1854 species, have a South African, Indo Pacific distribution. All these limpets were found to be infested with Mantoscyphidia branchi, but only C. r. capensis and S. exusta were infested with a mobiline peritrich. On the west coast of Africa (Gorée Island, Senegal), P. depressa and C. safiana were found to be infested with only a mobiline peritrich.

It is not difficult to explain how the leiotrochans from West Africa can belong to the species L. patellae, as the Boreal, Mediterranean and West African zoogeographical provinces are adjacent, with at least a few species of limpets overlapping in their distribution between these provinces. If one reasons that the South African east coast leiotrochans are indeed the same as the population from Dakar and the Boreal province, based on morphological features, it would suggest that it must have distributed via the Mediterranean-Red Sea link. It is well-known that this area was linked in recent geological times. We would like to suggest that this indeed was the route of distribution. Presently the Mediterranean is permanently linked to the Red Sea via the Suez Canal.

In conclusion, the small differences between the two populations from African limpets are not sufficient to warrant differentiation on species level, we therefore suggest that both populations be considered as Leiotrocha patellae. 


\section{REFERENCES}

Akşit D., Falakali-Mutaf B., Göçmen B., Gürelli G. Akşit D., Falakali-Mutaf B., Göçmen B., Gürelli G. (2008) A preliminary observations on Trichodina sp. (Ciliophora: Peritricha) on the gills of limpets (Patella sp.) in Antalya (Turkey). Art 4: 295-299

Avtalian R. R. (1981) Environmental control of the immune response in Fish. CRC Critical Reviews in Environmental Control, Boca Raton, Florida

Beers C. D. (1964) Urceolaria spinicola n. sp. an epizioc ciliate (Peritrichida: Mobilina) of sea urchin spines and pedicellariae. J. Protozool. 11: 435-437

Brouardel J. (1951) Sur la Biologie D’un Infusoire Péritriche commensal Des Patelles Urceolaria patellae (Cuénot). Ann. Inst. Oceanogr. 26: 115-254

Caullery M., Mesnil F. (1915) Sur Trichodina patellae (Cuénot) (symbiose avec des zooxantellae, structure, division, conjugation). C. R. Soc. Biol., Paris 78: 674-677

Corliss J. O. (1979) The Ciliated Protozoa-Characteristics, classification and guide to the literature, $2^{\text {nd }}$ ed. Pergamon press, Oxford

Cuénot L. (1891) Infusoires commensaux des Ligies, Patellase et Arenicoles. Rev. Biol. du Nord de la France 3: 81-89

Fenchel T. (1965) Ciliates from Scandinavian molluscs. Ophela 2: $71-174$

Haider G. (1964) Monographie der familie Urceolariidae (Ciliata, Peritricha, Mobilina) mit besonder Berücksichtigung der im süddeutscen Raum vorkommenden Arten. Parasitologische Schriftenreihe, 17 Fischer Jena

Hirshfield H. I. (1949) The morphology of Urceolaria karyolobia sp. nov., Trichodina tegula sp. nov. and Scyphidia ubiquita sp. nov., three new species from Southern California limpets and turbans. J. Morphol. 85: 1-28

Hirshfield H. I. (1950) The protozoan fauna of some species of intertidal invertebrates in southern California. J. Protozool. 36: $107-112$

Humason G. L. (1979) Animal Tissue Techniques. W. H. Freeman and Company, San Francisco

Irwin N. A. T, Lynn D. H. 2015. Molecular phylogeny of mobilid and sessilid ciliates symbiotic in Eastern Pacific limpets (Mollusca: Patellogastropoda). J. Eukaryot. Microbiol. 62: 543-552

Irwin N. A. T., Sabetrasekh M., Lynn D. H. (2017) Diversification and phylogenetics of mobilid peritrichs (Ciliophora) with description of Urceolaria parakorschelti sp. nov. Protist 168: 481-493

Khan R. A. (1990) Parasitism in marine fish after chronic exposure to petroleum hydrocarbons in the laboratory and to the Exxon Valdez oil spill. Bull. Environ. Toxicol. 44: 759-763

Khan R. A., Kiceniuk J. (1984). Histopathological effects of crude oil on Atlantic cod following chronic exposure. Can. J. Zool. 62: $2038-2043$
Khan R. A., Thulin J. (1991) Influence of pollution on parasites of aquatic animals. Adv. Parasitol. 30: 201-238

Klein B. M. (1958) The dry silver method and its proper use. J. Protozool. 5: $99-103$

Lee J. J., Hunter S. H., Bovee E. C. (1985) Illustrated guide to the Protozoa. Society of Protozoology, Lawrence, USA

Lom J., De Puytorac P. (1994) Sous-Classe Des Peritrichia Stein, 1859. In: Traité de Zoologie. Anatomie, Systematiques, Biologie, Infusoires Ciliés, (Ed. Grassé P. P.). Tome II Infusoires Ciliés, Fasc 2. Masson, Paris, 681-737

Lom J., Dykova I. (1992) Development in Aquaculture and Fisheries Science, volume 26. Protozoan Parasites of Fishes. Elsevier, Amsterdam

Lynn D. H. (2008) The Ciliated Protozoa: Characterization, Classification and Guide to the Literature. Springer, Berlin

Noble G. A. (1940) Trichodina urechi n. sp., an entozoic ciliate from the echiuroid worm, Urechis caupo. J. Parasitol. 26: 387-405

Palm H. W., Dobberstein R. C. (1999) Occurrence of trichodinid ciliates (Peritricha: Urceolariidae) in the Kiel Fjord, Baltic Sea and its possible use as a biological indicator. Parasitol. Res. 85: 726-732

Raabe Z. (1961) On the unknown cortical structure in Urceolaria (Ciliata-Peritricga). Acta Parasitol. Pol. 9: 153-160

Raabe Z. (1963) Systematics of the family Urceolariidae Dujardi, 1841. Acta Protozool. 1: 121-138

Richards C. R. (1971) Urceolaria viridis n. sp. a ciliate (Peritrichida, Mobilina) with elongate symbiotic green algae. J. Protozool. 18: $410-413$

Stein G. A. (1974) Morphological patterns of ciliates of the family Urceolariidae (Peritricha: Mobilina) from some marine invertebrates. Zool. Zh. 53: 965-973

Suzuki S. (1950) Studies on the urceolariid ciliates of Japan. Bull. Yamagata Univ. Natur. Sci. 2: 181-218

$\mathrm{Xu}$ K., Song W. (1998) A morphological study on a new species of gill parasite, Urceolaria cheni nov. spec. from the clam Scapharca subcrenata. J. Fish. China 5: 13-17

Zhan Z., Xu K., Dunthirn M. (2012) Evaluating molecular support for and against the monophyly of the Peritrichia and phylogenetic relationships within the Mobilida (Ciliophora: Oligohymenophora). Zool. Scripta 42: 213-226

Zick K. (1928) Urceolaria korschelti n.sp. eine neue marine Urceolarine, nebst einem Überblick über die Urceolarinen. Z. Wissen. Zool. 137: 356-403

Received on $9^{\text {th }}$ June, 2017; revised on $1^{\text {st }}$ December, 2017; accepted on $14^{\text {th }}$ December, 2017 